一原著一

車のランプ系ガラスの蛍光 X 線分析法および放射光蛍光 X 線分析法による識別の検討

\author{
吉田 努*1，鈴木伸一 $* 2$, 矢板 毅*3 \\ 茨城県警察本部刑事部科学捜査研究所*1, 日本原子力研究開発機構*2,*3 \\ 干310-8550 茨城県水戸市笠原町978-6*1 \\ 干319-1195 茨城県那珂郡東海村白方白根 2-4*2 \\ = 679-5148 兵庫県佐用郡佐用町光都 1-1-1*3
}

\title{
Discrimination of the Glass of Car Lamps by Wavelength Dispersive X-ray Fluores- cence Analysis and Synchrotron Radiation X-ray Fluorescence Analysis
}

\author{
Tsutomu Yoshida*1, Shin-ichi Suzuki*2 and Tsuyoshi Yaita*3 \\ Scientific Criminal Investigation Laboratory, Ibaraki Prefectural Police H.Q. \\ 978-6 Kasahara-tyo, Mito-shi, Ibaraki 310-8550, Japan*I \\ Japan Atomic Energy Agency \\ 2-4 Shirakatasirane, Toukai-mura, Naka-gun, Ibaraki 319-1195, Japan*2 \\ Japan Atomic Energy Agency \\ 1-1-1 Kouto, Sayou-tyo, Sayou-gun, Hyogo 679-5148, Japan*3
}

(Received 3 June 2009; accepted 18 January 2010)

Qualitative analyses of trace elements in the glass for car lamps were performed by wavelength dispersive $\mathrm{X}$-ray fluorescence analysis (WD-XRF) and synchrotron radiation $\mathrm{X}$-ray fluorescence analysis $(\mathrm{SR}-\mathrm{XRF})$ for the discrimination of the car lamps. Glass samples were crushed into powder and a disc of the same shape prepared from the powder of each glass was used for WD-XRF and SR-XRF measurements under the same geometrical condition in order to make the comparison of the spectra more accurate. Comparison of peak intensities for elements ( $\mathrm{Fe}, \mathrm{As}, \mathrm{Sr}, \mathrm{Zr}$, $\mathrm{Sb}, \mathrm{Ba}$ and $\mathrm{Pb}$ ) detected by WD-XRF was effective for the discrimination of the glasses. In $\mathrm{SR}-\mathrm{XRF}$, difference in the peak intensities of $\mathrm{Fe}, \mathrm{As}, \mathrm{Sr}, \mathrm{Zr}$ and $\mathrm{Pb}$ was found in some of glass samples produced by a same manufacturer. Difference in the peak intensities for elements in glass samples was observed also in the elemental constitutions of glass samples for the same use. The differences in elemental constitution were observed also between the outer glass (bulb glass) and the inner glass (stem glass) within the same lamp. Both WD-XRF and SR-XRF are very powerful analytical techniques to discriminate glass of the car lamps. The constituent of elements obtained by these methods can provide information to some extent to assist in determining the manufacturer and specifications of the glass.

Key words: Car lamp, Glass, Element, WD-XRF, SR-XRF 


\section{緒 言}

交通事故のなかでも単独, 車対車などの物損事故 に対して, 歩行者や自転車運転者などが死傷する人 身事故で被疑者が事故後逃走した場合に, 被疑車両 が事故に関与したことを立証するために自動車のガ ラス片が鑑定資料として持ち込まれることがある。 交通事故のほか, ガラス片の鑑定は, 器物損壊事件 などでも嘱託される.

ガラスは日常生活の中で広く使われている工業製 品である. ガラスは原材料の溶融, 成形, 冷却, 加 工などの工程を経て製造されるが1)，用途によって 原材料や製造工程が異なる．板ガラスでは透明度の 高いものが日常よく利用されているが，透明度の低 いくもりガラスも用途に応じて利用されている。一 方で, 瓶ガラスでは着色や形状なども様々な種類が 製造されており, 強度と同時に内容物の保持や安全 性も重視される.

ガラスの分析方法としては, 物理的性質では屈折 率, 熱膨張分析など, 化学的性質では元素組成分析 や微量元素分析などがあり, 板ガラスなどを対象に 分析を行った研究がこれまでに報告されてい

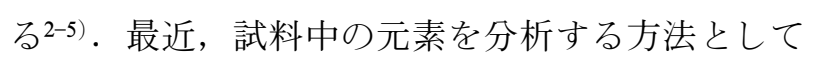
放射光蛍光 X 線分析法を利用した研究が法科学を はじめ多くの分野から報告されており, ガラスの異 同識別にも用いられるようになっている6,7).

自動車で使用されるガラス類は大きく分けてウィ ンドガラスと電球ガラスがある. ウィンドガラスで はフロントガラスで使用される合わせガラスや，そ れ以外で使用されている強化ガラスがある. 一方, 電球ガラスはヘッドランプのほか, ブレーキラン プ, ルームランプなど電球の種類自体が多い。 た, 一般的な乗用車のほかバス, トラック, 自動二 輪, 原動機付き自転車, 自転車などがあり, それぞ れに適合した電球が販売, 使用されている. 電球ガ ラスは, (1)照明を目的とする, (2)発生する熱に長時 間耐えられる, (3)食器のように食物之直接接触する ことは少ない, という特徵があるため, 板ガラス, 瓶ガラスなどでよく使われているソーダ石灰ガラス とは異なり，鉛ガラスや耐熱性のある石英ガラスが 使用されている種類もある8). また, 交通事故で四
輪車や二輪車などが大破すると，それらに装備され ている電球ガラスも破損して散乱する場合があり, 対象とする電球ガラス同士の異同識別を行う必要も 出てくることが考えられる.

本研究では車両に使用されている様々な仕様の電 球について，市販の装置を使用した蛍光 X 線分析 および放射光蛍光 X 線による定性分析を行った結 果を報告する，市販されている自動車用の各電球の ほか, バイク用, 自転車用の元素を分析し, 部位の 差, メーカーでどのような傾向の差があらわれるか を比較・検討した。

\section{実 験 \\ 1 ガラス試料の作製}

市販されている 8 社 27 種類の車両用電球ガラスを 準備した。仕様は普通乗用車用, トラック用, 二輪 車用, 自転車用のフォグランプ, テールランプ, ラ イセンスランプ, バックランプなどの電球ガラスを 選択した。試料のラベルは, メーカーの種類で A から $\mathrm{H}$ に分類した。 また,これらの電球の中には バルブと呼ばれる外側の電球ガラスのほかに，ステ ムと呼ばれるフィラメントを支える土台のガラスが 存在しているものもあり，それぞれが混ざらないよ うに慎重に分別し，ラベルはバルブとステムで区別 した．仕様の詳細を Table 1 に示す.

電球ガラスの破片は, メタノール中で超音波洗浄 器を使って洗浄し, 乾燥させた後, ボロンカーバイ ド乳鉢で粉砕した。その粉末の $25 \mathrm{mg}$ を秤量し，バ インダーとしてセルロースパウダー $5 \mathrm{mg}$ を加えて よく混ぜ合わせた。これを錠剤成型器と油圧圧縮器 でディスク型に成型し，ポリエチレン袋に封をした ものを測定試料とした。

\section{2 分析装置}

(1) 蛍光 X 線分析

蛍光 X 線分析は, 理学電機製 RIX3001（波長分 散型）蛍光 $\mathrm{X}$ 線分析装置で扔こなった。分析条件 を以下に示す。

管球 : ロジウム, 管電圧 : $50 \mathrm{keV}$, 管電 流 : $80 \mathrm{~mA}$

測定雾囲気 : 真空

ビーム径 : $3 \mathrm{~mm} \phi$ 
Table 1 List of the car-lamps.

\begin{tabular}{|c|c|c|c|}
\hline Sample & Vehicle type & Use & Stem $^{a)}$ \\
\hline A1 & Passenger cars & Turn signal, Back, Cornering & $\bigcirc$ \\
\hline $\mathrm{A} 2$ & Passenger cars & License & $x$ \\
\hline A3 & Passenger cars & Meter, Indicator & $x$ \\
\hline A4 & Passenger cars & Room, Luggage area & $x$ \\
\hline A5 & $\begin{array}{l}\text { (1) Passenger cars } \\
\text { (2) Mopeds and Motorcycl }\end{array}$ & $\begin{array}{c}\text { License } \\
\text { Turn signal }\end{array}$ & $\times$ \\
\hline A6 & Passenger cars & Fog & $\bigcirc$ \\
\hline A7 & Trucks and buses & Stop/Tail & $\bigcirc$ \\
\hline A8 & Trucks and buses & Turn signal, Back & $\bigcirc$ \\
\hline A9 & Trucks and buses & Side marker & 0 \\
\hline A10 & Mopeds and Motorcycles & Stop/Tail & $\bigcirc$ \\
\hline A11 & Mopeds and Motorcycles & Meter & $x$ \\
\hline A12 & Mopeds and Motorcycles & Head & $x$ \\
\hline A13 & Mopeds and Motorcycles & Head & $x$ \\
\hline A14 & Mopeds and Motorcycles & Stop/Tail & 0 \\
\hline A15 & Mopeds and Motorcycles & Turn signal & $\times$ \\
\hline $\mathrm{B} 1$ & Passenger cars & Cornering, Tail/Stop & $\bigcirc$ \\
\hline $\mathrm{C} 1$ & Passenger cars & Room & $x$ \\
\hline $\mathrm{C} 2$ & Passenger cars & Cornering, Tail/Stop & 0 \\
\hline D1 & Passenger cars & Back & 0 \\
\hline $\mathrm{D} 2$ & Passenger cars & Room, Map room & $x$ \\
\hline D3 & Passenger cars & Cornering & 0 \\
\hline E1 & Bicycles & Head & $x$ \\
\hline $\mathrm{F} 1$ & Bicycles & Head & $x$ \\
\hline G1 & Bicycles & Head & $x$ \\
\hline $\mathrm{G} 2$ & Bicycles & Head & $x$ \\
\hline G3 & Bicycles & Head & $x$ \\
\hline $\mathrm{H} 1$ & Bicycles & Head & $x$ \\
\hline
\end{tabular}

a) : $\bigcirc \cdots$ attached, $\times \cdots$ not attached.

$$
\begin{array}{ll}
\text { 分光結晶 } & : \mathrm{LiF} \\
\text { 走査速度 } & : 5 \sim 90^{\circ} \\
\text { ステップ } & : 0.02^{\circ} \\
\text { 時間 } & : 0.2 \mathrm{sec} . / \mathrm{step} \\
\text { 対象元素 } & : \text { カルシウムより原子番号の大きい元 } \\
& \text { 素 }
\end{array}
$$

\section{（2）放射光蛍光 X 線分析}

放射光蛍光 $\mathrm{X}$ 線分析は, 茨城県つくば市の高エ ネルギー加速器研究機構フォトンファクトリーの ビームライン27Bでおこなった．分析条件を以下に 示す.

\section{挿入光源 : 偏向電磁石}

$\mathrm{X}$ 線エネルギー : $15 \mathrm{keV}$ および $20 \mathrm{keV}$

$$
\begin{aligned}
& \text { 測定䨌囲気 : 大気 } \\
& \text { ビーム径 : 繸 } 2 \mathrm{~mm} \text {, 横 } 3 \mathrm{~mm} \\
& \text { 検出器：キャンベラ製 } 7 \text { 素子ゲルマニ } \\
& \text { ウム半導体検出器 } \\
& \text { 測定時間 : } 600 \mathrm{sec} \text {. } \\
& \text { 対象元素 : } \\
& \begin{array}{r}
\mathrm{X} \text { 線エネルギー } 15 \mathrm{keV} \cdots \text { 鉄, ヒ素，鉛 } \\
20 \mathrm{keV} \cdots \text { ストロンチウム, } \\
\text { ジルコニウム }
\end{array}
\end{aligned}
$$

特性 X 線のピークの有無および強度を測定して スペクトルを描き，各試料間の比較をおこなった。 


\section{結果と考察 \\ 1 蛍光 $\mathbf{X}$ 線分析法による分析結果}

蛍光 X 線分析の結果を Table 2 に示す。表では ピークの有無をプラスとマイナス，ピーク強度をプ ラスの数であらわした．分析の結果，全試料を通し てカルシウムより原子番号の大きい元素では，鉄， ヒ素，ストロンチウム，ジルコニウム，アンチモ ン, バリウム, 鉛が検出された。

鉄が検出されなかった試料は 1 試料だけであっ た.この試料は橙色の電球で，鉄のピークは確認で きなかったため，検出限界以下だと考えられる．ま た，メーカーの違い，バルブとステムの違いなどに よる鉄のピーク強度の差はほとんど見られなかっ た。

ヒ素が顕著に検出されたのは自転車用の 2 種類の 電球ガラスのみであった。これらの試料はヒ素の含 有量が比較的多く，また鉛との識別については鉛の $\mathrm{L}_{\beta}$ 線ピークが検出されていないことから鉛は検出 限界以下々判断した。しかし，七素であるか鉛であ るかの判定は，これらが重ならないヒ素の $\mathrm{K}_{\beta}$ 線や 鉛の $\mathrm{L}_{\beta}$ 線を使用するのが良いが，蛍光 $\mathrm{X}$ 線分析の 感度の点から, 含有量によってはこれらの特性 X 線が検出限界以下である場合があることに注意する 必要があった。

ストロンチウムは, 自転車用以外の電球では, 2000カウント以上検出された試料が半数以上あり, 検出されなかった試料はほとんどなかった．特に， ステムガラス，ステムを持たない電球ガラスでは, すべての試料から検出されたが，ステムを持つ電球 のバルブガラスは $\mathrm{A}$ 社の 1 試料および $\mathrm{D}$ 社を除い て検出されないか，ピーク強度が低かったかのどち らかであったＡ 社のバルブガラスでストロンチ ウムが顕著に検出されたのは, 橙色のフォグランプ であった。自転車用の電球では，検出されたのは 3 試料で，うち顕著に検出されたのは 2 試料であり, 検出されない試料が多かったことは自動車系電球力゙ ラスの傾向とは異なっていた。

アンチモンは，自転車用の電球以外では，ステム を持たない電球ガラスのすべてから検出された。 ま た，ステムを持つ電球のステムガラスとバルブガラ
Table 2 Analytical results of WD-XRF. ${ }^{\mathrm{a}}$

\begin{tabular}{|c|c|c|c|c|c|c|c|c|}
\hline Sample & Position & $\mathrm{Fe}$ & As & $\mathrm{Sr}$ & $\mathrm{Zr}$ & $\mathrm{Sb}$ & $\mathrm{Ba}$ & $\mathrm{Pb}$ \\
\hline \multirow[t]{2}{*}{ A1 } & Stem & + & - & $H$ & $H$ & - & $H$ & - \\
\hline & Bulb & + & - & $H$ & $H$ & - & - & - \\
\hline $\mathrm{A} 2$ & Bulb & + & - & WI & - & H & $H$ & - \\
\hline A3 & Bulb & + & - & WI & - & H & $H$ & - \\
\hline A4 & Bulb & + & - & m & - & $H$ & $H$ & + \\
\hline A5 & Bulb & + & - & m & - & H & $H$ & - \\
\hline \multirow[t]{2}{*}{ A6 } & Stem & + & - & m & - & H & $H$ & - \\
\hline & Bulb & - & - & m & - & - & $H$ & - \\
\hline \multirow[t]{2}{*}{ A7 } & Stem & + & - & $H$ & $H$ & - & $H$ & - \\
\hline & Bulb & + & - & - & $H$ & - & - & - \\
\hline \multirow[t]{2}{*}{ A 8} & Stem & + & - & $H$ & $H$ & - & $H$ & - \\
\hline & Bulb & + & - & - & H & - & - & - \\
\hline \multirow[t]{2}{*}{ A9 } & Stem & + & - & WI & - & H & H & - \\
\hline & Bulb & + & - & $H$ & $H$ & $H$ & - & - \\
\hline \multirow[t]{2}{*}{ A10 } & Stem & + & - & WI & - & $H$ & $H$ & - \\
\hline & Bulb & + & - & m & m & $H$ & - & - \\
\hline A11 & Bulb & + & - & m & - & $H$ & $H$ & - \\
\hline A12 & Bulb & + & - & $H$ & $H$ & $H$ & - & - \\
\hline A13 & Bulb & + & - & $H$ & $H$ & $H$ & - & - \\
\hline \multirow[t]{2}{*}{ A14 } & Stem & + & - & mI & - & $H$ & $H$ & - \\
\hline & Bulb & + & - & $H$ & $H$ & $H$ & - & - \\
\hline A 15 & Bulb & + & - & WI & - & $H$ & $H$ & - \\
\hline \multirow[t]{2}{*}{ B1 } & Stem & + & - & WI & - & $H$ & $H$ & - \\
\hline & Bulb & + & - & + & $H$ & $H$ & - & - \\
\hline $\mathrm{C} 1$ & Bulb & + & - & m & - & $H$ & $H$ & - \\
\hline \multirow[t]{2}{*}{$\mathrm{C} 2$} & Stem & + & - & WI & - & $H$ & $H$ & - \\
\hline & Bulb & + & - & + & $H$ & $H$ & - & - \\
\hline \multirow[t]{2}{*}{ D1 } & Stem & + & - & mI & - & $H$ & $H$ & - \\
\hline & Bulb & + & - & m & $H$ & $H$ & - & - \\
\hline D2 & Bulb & + & - & mI & - & H & $H$ & - \\
\hline \multirow[t]{2}{*}{ D3 } & Stem & + & - & WI & - & $H$ & H & - \\
\hline & Bulb & + & - & m & $H$ & $H$ & - & - \\
\hline E1 & Bulb & + & - & mI & - & - & $H$ & - \\
\hline $\mathrm{F} 1$ & Bulb & + & - & - & - & - & - & mI \\
\hline G1 & Bulb & + & H & - & $H$ & - & - & - \\
\hline $\mathrm{G} 2$ & Bulb & + & - & WI & - & $H$ & $H$ & - \\
\hline G3 & Bulb & + & m & $H$ & $H$ & - & - & - \\
\hline $\mathrm{H} 1$ & Bulb & + & - & - & - & - & - & mI \\
\hline
\end{tabular}

a) : $+\cdots$ less than 20 counts.

H. 20 to 100 counts.

$\mathrm{H} \cdot \cdot 100$ to 2000 counts.

WI ' more than 2000 counts.

スでは検出されたものと，そうでないものがあった が， 1 試料を除いて，ステムガラスとバルブガラス の両方から検出されたか, 両方から検出されなかっ 
たかのどちらかであった. よって，アンチモンの存 在はバルブガラスかステムガラスかにほとんど無関 係であると考えられた．ピーク強度は何れの試料も ほぼ同じであったため，定性分析による識別が効果 的であると考えられる.

バリウムは，ステムガラス，ステムを持たない電 球のバルブガラスでは, ほとんどの試料から検出さ れたが，ステムを持つ電球のバルブガラスではほと んどの試料で検出されず，この傾向はストロンチウ ムと似ている. バリウムのピーク強度は, 検出され たほかの試料でほぼ同じであった。バリウムの含有 量の比較はガラスの分類に効果的であるという報告 があるが9)，今回の結果では定性分析による識別の 指標となり得ると考えられた。

鉛は, 自転車用の 2 試料のほか, 他系列の 1 試料 で検出された。自転車用の電球ではかなり強いピー クが検出されたが，通常の車用ランプ電球ではこの 条件ではほとんど検出されることがなかった。

\section{2 放射光蛍光 $\mathbf{X}$ 線分析による分析結果}

放射光蛍光 $\mathrm{X}$ 線分析の結果を Table 3 に, 各試 料のスペクトルをFig. 1 から Fig. 4 に示す. 図は それぞれ, 左から市販の装置, 放射光で入射 $\mathrm{X}$ 線 エネルギーを $15 \mathrm{keV}$ あるいは $20 \mathrm{keV}$ に設定したと きのスペクトルを示した。 また，Fig. 1 は乗用車 用，Fig. 2 はトラックおよびバス用，Fig. 3 は二輪 車用, Fig. 4 は自転車用に仕様されているものであ る. 入射 $\mathrm{X}$ 線エネルギーが $15 \mathrm{keV}$ では鉄, 七素, 鉛を, $20 \mathrm{keV}$ ではストロンチウム, シルコニウム をそれぞれ測定対象にした。いずれのエネルギーの 場合も，入射 $\mathrm{X}$ 線による弾性散乱および非弾性散 乱に基づく元素以外のピークが検出されていたた め, 同時に測定したブランク試料のスペクトルと比 較して詳細なピークの帰属を行い，その上で元素 ピークの有無および強度による比較を行った。ブラ ンク試料では, 鉄, 亜鉛, 臭素, 鉛が検出された.

このうち, 亜鉛, 臭素は実試料とピーク強度が同程 度であったため，スペクトル中では BG と示した.

これらは，測定試料を封した際に使用したポリエチ レン袋, 固定するホルダー, 固定する際に使用した テープに由来するものと考えられる，鉄，鉛は実試 料の方がピーク強度の高いものが多かったため, 試
Table 3 Analytical results of SR-XRF.a)

\begin{tabular}{|c|c|c|c|c|c|c|}
\hline Sample & Position & $\mathrm{Fe}$ & As & $\mathrm{Sr}$ & $\mathrm{Zr}$ & $\mathrm{Pb}$ \\
\hline \multirow[t]{2}{*}{ A1 } & Stem & + & - & + & W & + \\
\hline & Bulb & + & - & + & H & + \\
\hline $\mathrm{A} 2$ & Bulb & + & - & WI & \pm & + \\
\hline A3 & Bulb & + & - & mI & \pm & + \\
\hline A4 & Bulb & + & - & WI & \pm & m \\
\hline A5 & Bulb & + & - & WI & \pm & - \\
\hline \multirow[t]{2}{*}{ A6 } & Stem & + & - & WI & \pm & H \\
\hline & Bulb & + & - & mI & \pm & - \\
\hline \multirow[t]{2}{*}{ A7 } & Stem & + & - & H & W & + \\
\hline & Bulb & H & - & - & H & + \\
\hline \multirow[t]{2}{*}{ A8 } & Stem & + & - & H & W & + \\
\hline & Bulb & H & - & - & $H$ & + \\
\hline \multirow[t]{2}{*}{ A9 } & Stem & + & - & m & \pm & + \\
\hline & Bulb & + & - & W & W & H \\
\hline \multirow[t]{2}{*}{ A10 } & Stem & + & - & WI & \pm & + \\
\hline & Bulb & + & - & W & H & $H$ \\
\hline A11 & Bulb & + & - & m & \pm & + \\
\hline A12 & Bulb & + & - & + & $H$ & + \\
\hline A13 & Bulb & + & - & + & H & + \\
\hline \multirow{2}{*}{ A14 } & Stem & + & - & WI & \pm & - \\
\hline & Bulb & + & - & + & H & - \\
\hline A15 & Bulb & + & - & WI & \pm & + \\
\hline \multirow[t]{2}{*}{$\mathrm{B} 1$} & Stem & + & - & WI & \pm & + \\
\hline & Bulb & + & - & + & $H$ & + \\
\hline $\mathrm{C} 1$ & Bulb & + & - & WI & \pm & + \\
\hline \multirow[t]{2}{*}{$\mathrm{C} 2$} & Stem & + & - & m & \pm & + \\
\hline & Bulb & + & - & + & $H$ & - \\
\hline \multirow[t]{2}{*}{ D1 } & Stem & + & - & WI & \pm & $H$ \\
\hline & Bulb & + & - & WI & H & + \\
\hline D2 & Bulb & + & - & mI & \pm & - \\
\hline \multirow[t]{2}{*}{ D3 } & Stem & + & - & WI & \pm & - \\
\hline & Bulb & + & - & m & H & + \\
\hline E1 & Bulb & + & - & mI & - & $H$ \\
\hline $\mathrm{F} 1$ & Bulb & + & - & - & - & mI \\
\hline G1 & Bulb & W & WI & - & $H$ & - \\
\hline G2 & Bulb & + & - & m & \pm & $H$ \\
\hline G3 & Bulb & W & WI & + & $H$ & - \\
\hline H1 & Bulb & + & - & - & - & WI \\
\hline
\end{tabular}

a) : $+\cdots$ less than 100 counts.

H $\cdot 100$ to 250 counts.

HW $\cdot 250$ to 500 counts.

HW ' more than 500 counts.

料によって個別に判定した. ニッケルはピーク強度 がブランクより高いものがあったが，由来が不明で あり，判定には用いなかった。 

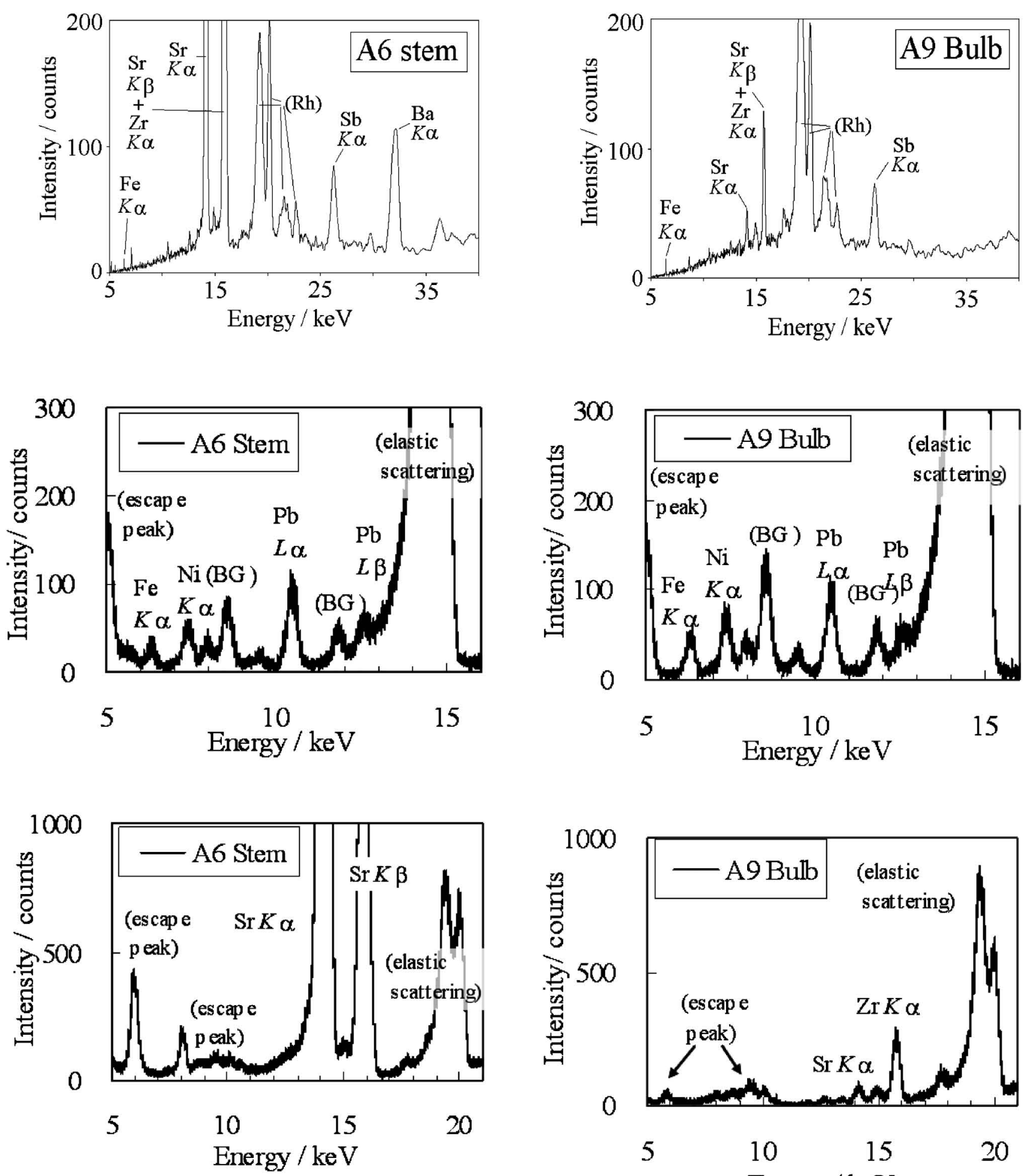

Fig. 1 The XRF spectra of glass samples of passenger cars.

(Top: WD-XRF, Center: SR-XRF by $15 \mathrm{keV}$, Bottom: SR-XRF by $20 \mathrm{keV}$ )

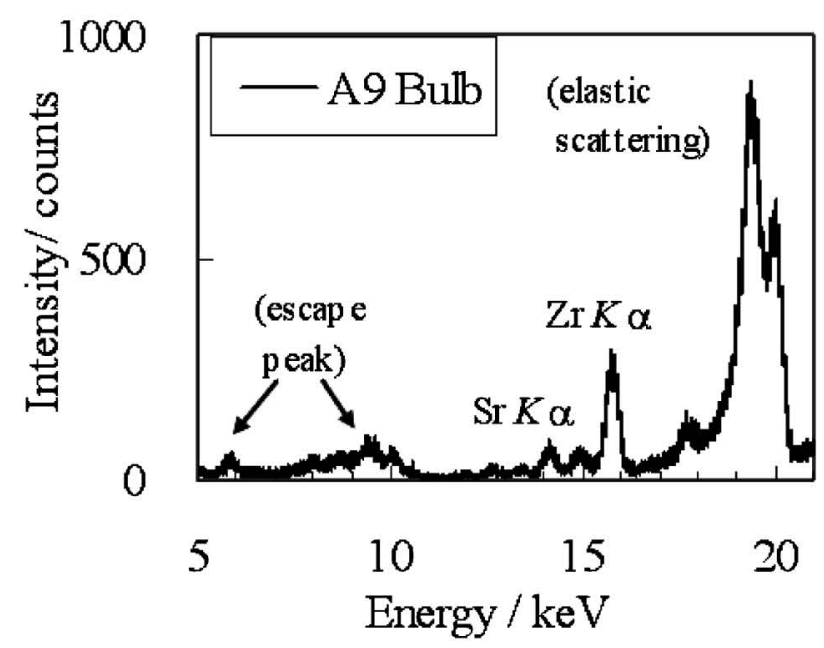

Fig. 2 The XRF spectra of glass samples of trucks and buses.

(Top: WD-XRF, Center: SR-XRF by $15 \mathrm{keV}$, Bottom: SR-XRF by $20 \mathrm{keV}$ ) 

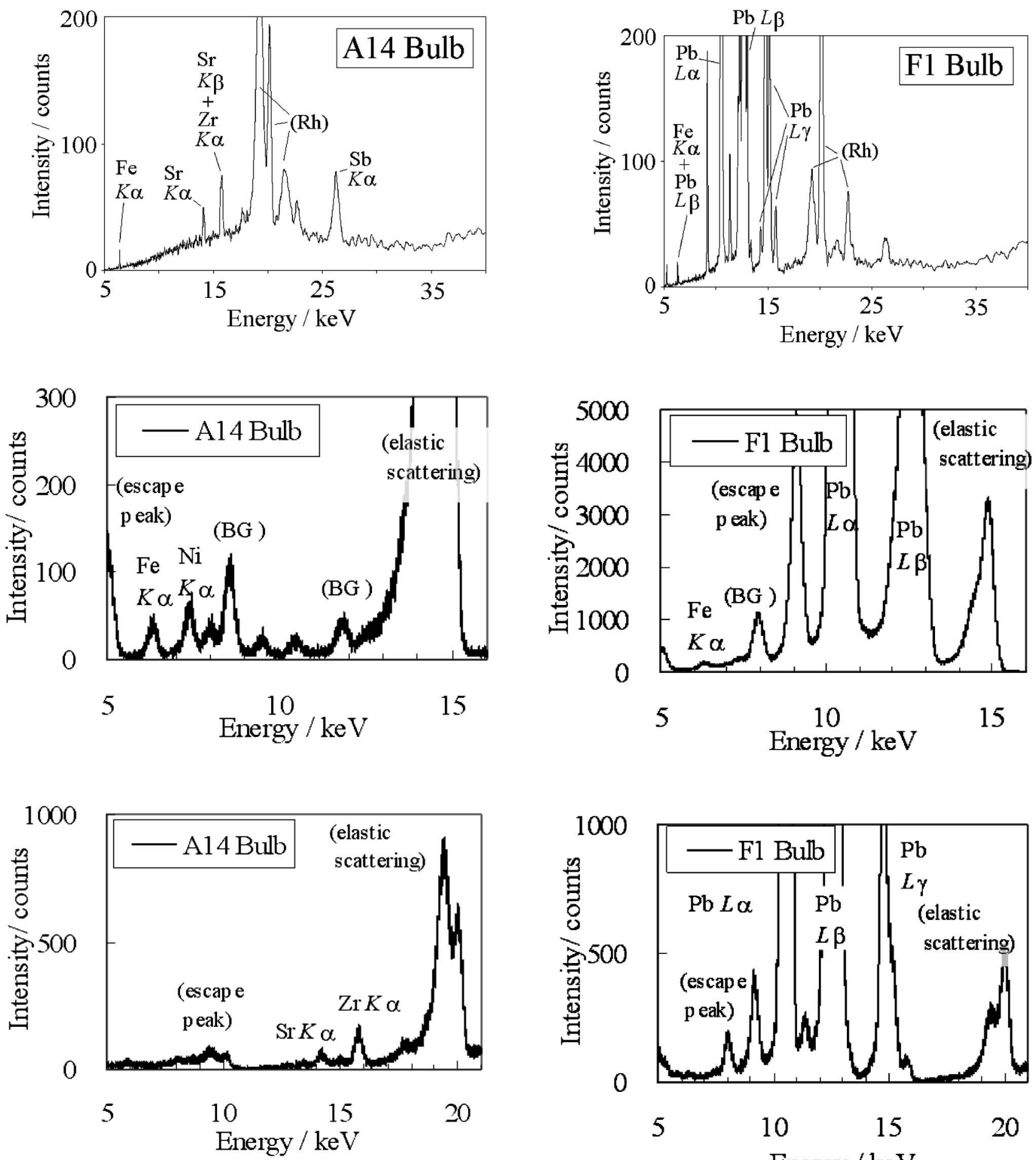

Fig. 3 The XRF spectra of glass samples of mopeds and motorcycles.

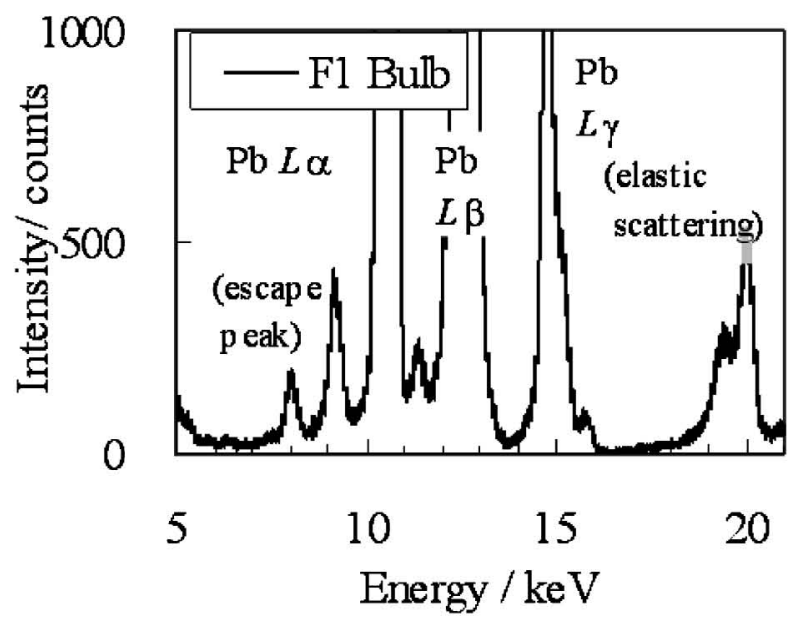

Fig. 4 The XRF spectra of glass samples of bicycles. (Top: WD-XRF, Center: SR-XRF by $15 \mathrm{keV}$, Bottom: SR-XRF by $20 \mathrm{keV}$ )

(Top: WD-XRF, Center: SR-XRF by $15 \mathrm{keV}$, Bottom: SR-XRF by $20 \mathrm{keV}$ ) 
$\mathrm{X}$ 線分析の場合, 照射面積が小さいと, 照射部 位によるばらつきの影響で測定の再現性が低下する 可能性が考えられる. 今回の実験では, 同じ方法で 作成した $3 つ の$ 試料について 2 回ずつ測定して対象 元素のピーク強度を測定した結果, その標準䛊差は 平均值のおよそ7\%であった。これは, 今回のビー 厶径は $2 \mathrm{~mm} \times 3 \mathrm{~mm}$ であり, 試料の表面は平滑に してあるため, その試料の平滑面に当たっていれば 差はほとんどないためと考えられる.

鉄は，すべての試料でピークが検出され，ブラン ク試料と比較してもピーク強度が有意に高いものが ほとんどであった。市販の装置による分析時には検 出が不可能だった試料についてもピークを確認する ことができた。 また，100カウントを超えない試料 と, 超える試料を識別ができる可能性が認められ た. 自転車用電球類の一部の試料で, $\mathrm{X}$ 線エネル ギー設定值を $15 \mathrm{keV}$ にしたとき， $5 \mathrm{keV}$ 付近の非弾 性散乱ピーク（エスケープピーク）が, 他の電球類 より高かったが，これは弾性散乱ピークが他の試料 より大きかったことが原因であり, 鉄のピークを検 出することには影響はなかった．バルブとステムが ある電球の場合, 同一の試料でもステムよりバルブ の鉄のピークが高いものはあったが，ほとんどの試 料ではほぼ同じであった. 同一メーカー内でもステ ム同士，バルブ同士で元素ピークが異なるものがあ ったが，メーカーが異なればガラスのスペクトルは 大きく異なるということはなく, 種類によっては類 似する試料もあった。

七素は，市販の装置で検出された試料ではいずれ も顕著に検出されたが，他の試料では検出されず， 市販の装置と同じ傾向を示した.

ストロンチウムは, 市販の装置とほとんど同様の 結果を示した. ステムのない電球のバルブガラス と, ステムのある電球のバルブガラスの比較でも市 販の装置とほとんど同じ結果であった.

ジルコニウムは, 市販の装置と同様にストロンチ ウムが顕著に検出された試料ではストロンチウムの $\mathrm{K}_{\beta}$ 線のために検出されたかどうかを判定すること は不可能であった，ただ，ストロンチウムが多い試 料の中にはジルコニウムの $\mathrm{K}_{\beta}$ 線 $(17.6 \mathrm{keV})$ が弾 性散乱ピークのショルダーで認められるものがあり
(Table 3 で土と表した試料), 測定条件をさらに改 良することで確実に検出できる可能性があると思わ れた. ジルコニウムが検出された試料ではピーク強 度には差がみられたものもあり，試料間の識別に利 用できる可能性があると考えられた.

市販の装置で検出されたアンチモン，バリウム は，適切な特性 $\mathrm{X}$ 線のエネルギー值が測定可能な エネルギー範囲内になかったこと, 他元素の散乱 ピークの影響が無視できないなどの理由のため検出 することはできなかった。

鉛は, 市販の装置と同様, 自転車用で顕著に検出 された試料があった。 また，他の試料においても， $\mathrm{X}$ 線エネルギー設定值が $15 \mathrm{keV}$ の時には， $\mathrm{L}_{\alpha}$ 線と $\mathrm{L}_{\beta}$ 線の両方のピークが認められた試料と $\mathrm{L}_{\alpha}$ 線の ピークと $\mathrm{L}_{\beta}$ 線のショルダーが認められた試料が多 く，市販の装置より検出できた試料が多かった.

\section{3 考察}

通常ガラスの分析には, 幅広く高感度で分析でき る誘導結合プラズマ質量分析法 (ICP-MS) がよく 使用されている，ただしこの方法には，(1)溶液化す るために試料が消費される，(2)質量数80以下の領域 でマトリックス由来の多原子イオンによる妨害のた め, 原子番号の小さい軽元素の分析が困難という問 題点がある. そこで本研究では，試料を消費せず， $\mathrm{X}$ 線のエネルギー值の設定を変えることで軽元素 もターゲットにすることができ, 高いX $\mathrm{X}$ 線が利用 できれば多元素同時分析も可能な蛍光 $X$ 線の応用 について検討した。なお，放射光蛍光 $\mathrm{X}$ 線分析で は波長分散型の装置がよく議論されているが，今回 は最も簡素な方法を使ってどの程度の分析および異 同識別が可能かを検討するために，エネルギー分散 型の検出器を用いた.

電球ガラスには球形や円筒形の部分が多いため, 破壊されたときのガラス片も完全な平面を有するこ とは考えにくい.したがって, 複数個の試料を比較 する場合, 分析した元素のピーク強度の相対比で表 すことが多い、今回の実験ではガラス片を粉砕して 表面が平滑なディスク型にしたため, 分析試料の形 状による蛍光 X 線の誤差をほとんど無視すること ができる上，スペクトルの直接比較や定量分析への 応用が考えられる，ただ，粉末にして錠剤化する操 
作により試料の密度がガラスを粉砕する前より低下 するため，感度は若干低下し，ガラスを粉砕する前 とピーク強度を比較すると約 $1 / 5$ から $1 / 10$ になっ たが，測定時間を調整することで強度を補うことが できると考えられる．検出限界は市販の装置では約 $150 \mathrm{ppm}$ (鉄)，放射光蛍光 X線分析では約 $40 \mathrm{ppm}$ (鉄) であった.

放射光蛍光 $\mathrm{X}$ 線分析で, $\mathrm{X}$ 線エネルギーを 15 $\mathrm{keV}$ と $20 \mathrm{keV}$ に設定した場合を比較すると，10 $\mathrm{keV}$ 近辺のピーク強度に差があらわれた．X線を20 $\mathrm{keV}$ に設定するとストロソチウムやジルコニウムが 効率よく検出されたが，それよりエネルギーの低い 元素のピーク強度は低かった．X線を $15 \mathrm{keV}$ に変 更することで，他の元素のピークを検出することが できた．特に，20 keVに設定したときには鉄や鉛 のピークがほとんど認められなかった試料であって も，15 keVに設定することで検出できたものが複 数あったため, 微量の鉄や鉛を目的にするときは15 $\mathrm{keV}$ を選択するのが望ましいと考えられた。 また， 今回は測定時間を600秒でおこなったが，測定時間 を長くすることでピーク強度が増して試料間の識別 がしやすくなり，さらに計数誤差も小さくなると考 えられる。

メーカーや用途の識別に有効な元素を Table 4 に まとめて示す。自転車の電球から七素など特徵のあ る元素の検出されたことや，一般に存在量の多いス トロンチウムの含有量が少なかったことなどは, こ れらの元素が異同識別の有効な指標になりうる可能 性を示しており, 蛍光 X線分析の有用性が合わせ て示唆された。 それ以外の電球では, メ一カー特有 という元素は特になく，共通して検出された元素が 多かった.しかし，同じメーカーでも仕様によって 元素の強度が異なる種類が多かった。ささらに, フィ ラメントを支えるステムの存在はその電球ガラスの 元素組成に大きく影響していた．ステムはジュメッ トと呼ばれる導入線と封着させやすくするために以 前は鉛ガラスが使用されていたが，最近は鉛がほと んど含まれないガラスに替わってきている8). 今回 の結果では, ステムガラスではストロンチウムが顕 著に検出された。よって自動車用に使われている同 一電球でのバルブとステムの識別では, ストロンチ
Table 4 Useful elements for the discrimination of lamp glasses.

\begin{tabular}{ll}
\hline \multicolumn{1}{c}{ Comparison } & \multicolumn{1}{c}{$\begin{array}{c}\text { Useful elements for the } \\
\text { discrimination }\end{array}$} \\
\hline $\begin{array}{l}\text { Passenger cars of differ- } \\
\text { ent manufactures }\end{array}$ & $\mathrm{Sr}, \mathrm{Zr}, \mathrm{Pb}$ \\
$\begin{array}{l}\text { Bicycles of different } \\
\text { manufactures }\end{array}$ & $\mathrm{Fe}, \mathrm{As}, \mathrm{Sr}, \mathrm{Zr}, \mathrm{Pb}$ \\
$\begin{array}{l}\text { Different vehicle types } \\
\text { Different uses }\end{array}$ & $\begin{array}{l}\mathrm{Sr}, \mathrm{Zr}, \mathrm{Pb} \\
\mathrm{Sr}, \mathrm{Zr}, \mathrm{Ba}, \mathrm{Pb} \\
\text { (Stop/Tail, Cornering, } \\
\text { Turn signal) }\end{array}$ \\
Bulb and Stem & $\mathrm{Sr}, \mathrm{Zr}, \mathrm{Ba}$ \\
\hline
\end{tabular}

ウムが最も重要な指標となりうると考えられる。 た, 鉄については放射光蛍光 X線分析の時にピー ク強度に差があらわれるものがあり，これを対象と した時に識別に利用できると考えられる.

市販の装置と放射光蛍光 $\mathrm{X}$ 線には, それぞれ以 下のような特徵が認められた. 市販の装置では, 放 射光蛍光 $\mathrm{X}$ 線と比較して広いエネルギ一範囲の元 素を定性分析できるため, 鉄, ストロンチウム, ヒ 素, ジルコニウム, 鉛に加えて, 放射光蛍光 X 線 分析では検出できなかったアンチモンとバリウムを 異同識別に用いることが可能であった。これらはい ずれもガラスの分析で異同識別の手がかりになるこ とが多い元素であり, さらに強度を稼ぐことで識別 に抢ける重要な指標となると考えられる. 放射光蛍 光 $\mathrm{X}$ 線分析では使用したビームラインの制限から 元素の種類は限定されるものの, 市販の装置よりも 高い感度を活用して定性分析にピークの強度を指標 として加えることができた．特に鉄と鉛は，市販の 装置では判定できなかったピーク強度の差が見られ た試料も多く, 試料の異同識別に有効な情報を加え ることが可能であった.

以上のように, 今回の研究では(1)感度は高いが分 析可能元素の領域が限られてしまう放射光蛍光 X 線と, (2)感度は低いが, 広範囲に元素を定性分析で きる市販の装置を組み合わせ, 相互のデータを補完 することで, 電球ガラスについて Table 2, Table 3, 抢よび Fig. 1〜4に示すように, 一層詳細な分 析結果を得ることができた。 


\section{参考文献}

1）作花済夫, 境野照雄, 高橋克明 : ガラスハンド ブック. pp. 281-502, 朝倉書店, (1975).

2) John I. Thornton: The use of $k$ value in the interpretation of glass density and refractive index data., J. Forensic Sci., 34(6), 1323-1328 (1989).

3）田中 実, 鈴木 蕃, 今井俊多, 金子拓己: 都 市ゴミ焼却灰を主原料として用いた建材用結晶化 ガラスの開発. 東京都立産業技術研究所研究報 告, 8, 31-34 (2005).

4) Blacklock E. C., Rogers A., Wall C. and Wheals B. B.: The quantitative analysis of glass by emission spectrography: A six element survey. Forensic Sci., 7, 121-130 (1976).

5) D. A. Hickman: Elemental analysis and the discrimination of sheet glass samples. Forensic Sci.
Int., 23, 213-223 (1983).

6）鈴木康弘，笠松正昭，杉田律子，太田彦人，鈴 木真一, 丸茂義輝 : 放射光蛍光 $\mathrm{X}$ 線分析法及び 誘導結合プラズマ質量分析法によるへッドライト ガラス中微量不純物の分析と法科学的異同識別へ の応用. 分析化学, 52, 469-474 (2003).

7) Suzuki S., Suzuki Y., Ohta H., Kasamatsu M. and Nakanishi T.: Evaluation of a quantitative method for trace impurities in arsenous acids by synchrotron radiation $\mathrm{x}$-ray fluorescence spectrometry and inductively coupled plasma-atomic emission spectrometry. Anal. Sci., 21, 775-778 (2005).

8）鈴木英俊 : ガラスの百科事典. pp 210-213, 朝 倉書店，（2007）.

9) Hickman D. A.: A classification scheme for glass. Forensic Sci. Int., 17, 265-281 (1981). 